\title{
SOCIALIZATION OF INDIGENOUS COMMUNITY RIGHTS IN THE MANAGEMENT OF LAND RIGHTS IN THE TOGUTIL COMMUNITY OF EAST HALMAHERA
}

\author{
St. Laksanto UTOMO'*, Nam RUNGKEL ${ }^{2}$, Gatot Rambi HASTORO ${ }^{3}$ \\ ${ }^{1,3}$ Sahid University, Indonesia \\ ${ }^{2}$ Khairun University, Indonesia \\ *laksanto@gmail.com
}

\begin{abstract}
This community service activity is motivated by the worsening position of Indigenous Rights that are already rooted in the lives of indigenous peoples. Weak socialization and public understanding of the importance of law that can protect themselves from the progress of the times, so this community service has the aim of (1) providing an understanding so that customary rights with their local wisdom can be protected by the government in the form of regional regulations so that in the future whoever will lead will still have legal certainty, (2) Encourage local governments to immediately make regulations (customary regulations) that can protect the rights of local indigenous peoples. This activity is a socialization of regulations so that indigenous peoples know that their rights can be protected by the government in the form of local regulations. This can be seen from the presence of one of the tribes (Togutil) at the activity location who is still living in the Halmahera forest, North Maluku, whose existence is in a mining area that has the potential to be exploited and they are vulnerable to not being involved in the management of the results, let alone being able to share it to be utilized. as much as possible for their prosperity and welfare as mandated by the 1945 Constitution, because there is no central government or local government policy that reflects the existence of the Togutil tribe as the most important part in the management of natural resources. The conclusion of this socialization activity received a positive response from the community, marked by the start of the drafting of a regional regulation with support from local academics and other related parties so that indigenous peoples will receive legal certainty over their rights.
\end{abstract}

Keywords: Customary Rights, Protection, Customary Regional Regulation, Togutil Tribe, North Halmahera

\section{BACKGROUND}

The principle and direction of agrarian reform as well as a paradigm shift in the management of decentralized government through the granting of responsible autonomy to the regions, Presidential Decree Number 34 of 2003 was issued in which part of the government's authority in the land sector is carried out by the district/city government, including the determination and resolution of ulayat land issues. Based on these provisions, the rights of indigenous peoples must still exist and not be given the opportunity to be re-established. This existence must be followed by the relationship of use between the land and the community. While the community in question is a group of people who are bound by their customary law order, as joint citizens of a legal alliance, because of the similarity of residence or because of descent, known by various different names in each region.

North Maluku, which is known (Moloku Kie Raha) as a royal area (Ternate, Tidore, Bacan, and Jailolo), has long been familiar with the customs that govern people's lives, including the control and management of natural land resources. Land tenure systems are known in the form of private ownership and communal ownership systems, such as land tenure in the form of Sultan rights (aha kolano), soa rights (aha soa) and cocatu rights (aha cocatu) which have different functions and positions. The aha kolano is intended for the sultan and is not taxed from the land. Aha Soa (soa kampong) is the land given by the sultan to the clan and it is not allowed to buy and sell while the aha cocatu land is the land given by the sultan to be managed individually with a profit sharing system in the form of tribute.
In addition, there is also known temporary land tenure. The pattern of land tenure above in its development is increasingly marginalized due to land law politics that do not firmly regulate and protect the rights of local indigenous peoples, and are internally influenced by community developments that tend to leave Se Atorang adat (behavior according to customs). As a result, there is a struggle for land both by the government, businessmen and between communities. The government and businessmen are considered to have taken community land without any equal compensation. The community feels neglected and does not get the benefits of land which incidentally has been controlled for generations and has become their source of life.

Over time, the North Maluku region began to show its natural beauty which automatically invited local and foreign investors to invest in the context of developing tourism potential in addition to its enormous wealth of land.

This is a source of disaster for the indigenous peoples around their rights after they will begin to explore their natural wealth and beauty with various managements so that their rights are marginalized.

Ternate City Regulation No. 13 of 2009 concerning the Protection of Indigenous and Cultural Rights of the Indigenous Peoples of the Sultanate of Ternate is deemed less accommodating of the rights of indigenous peoples so far because it is only limited to the culture and rights around the Sultanate of Ternate which are less detailed on future problems.

\section{Partner Problems.}

Ternate City Regulation No. 13 of 2009 which regulates the protection of customary rights and community culture 
only applies to the Sultanate of Ternate and has not been able to fulfill all areas of several tribes in North Halmahera. This is related to the increasing number of tourism potentials and natural resources found in the area, so that indigenous peoples are increasingly eroded by their rights and lands if they are not supported by a local regulation (PERDA) that protects them.

Over time, indigenous peoples do not yet have a strong grip to be able to maintain and bargain if the area is started to be explored related to tourism and other natural resources by investors (mainly foreign) for the recognition of land rights and customary rights, contribution of proceeds and others, so that indigenous peoples feel marginalized and have the potential to create conflicts between ethnic groups in various interests.

\section{METHOD}

The activity involved traditional leaders and the Regional Government Work Unit (SKPD) in the Bicoli District, Maba Regency, East Halmahera as the target. This community service activity used an approach in the form of socialization. Besides that, activities were carried out to visit the Togutil tribes in the interior in some of the places where they live by conducting direct dialogue about the condition of their customary rights, with the hope that after the implementation of this socialization activity, an understanding of their rights that must be protected by the local government will grow in accordance with their local wisdom.

The steps that have been carried out in this community service activity are as follows.

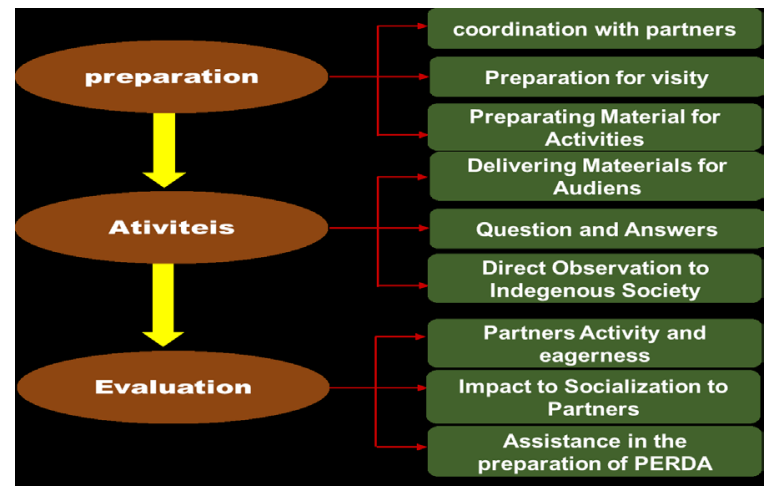

Figure 1. schedule of activities

\section{RESULTS AND DISCUSSION}

In carrying out this activity, the executor of community service activities collaborated with the Postgraduate Program at Kahirun University, Ternate and Bicoli sub-district, Maba Maba, North Halmahera. The form of the activity was carried out in the form of a discussion led by a moderator of the Faculty of Law, University of Khairun Ternate, this activity was attended by 25 participants who came from traditional community leaders who incidentallyhave become one of the village officials, traditional leaders and the Bicoli community. In the discussion, there was an explanation by the executor of community service followed by a question and answer dialogue

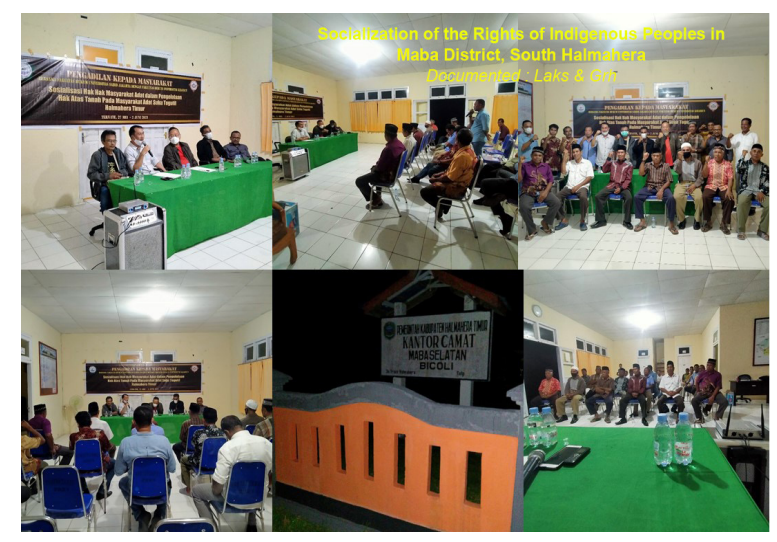

Figure 2. Socialization of The Right of indegeneus peoples in Maba District

Law of the Republic of Indonesia Number 5 of 1960 concerning Basic Regulations on Agrarian Principles in article 5 reads "Agrarian law applicable to earth, water and space is customary law, as long as it does not conflict with national and state interests, which is based on national unity., with Indonesian socialism as well as with the regulations contained in this Law and with other laws and regulations, everything by taking into account the elements that rely on religious law.

In the implementation of the extension activities, various problems were expressed by traditional leaders related to the management of their territory's land, namely about the tourism potential that is increasingly being found and several existing and managed mines in the area including: 1). PT Aneka Tambang Maronopo site, Apart from mining for nickel, Antam is also building a nickel smelter, located at Maba Pura, 2). PT. FENI HALTIM is a subsidiary of PT ANTAM Tbk, 3). PT Yudistira Bumu Bakti. Meanwhile, in mining companies, there are many foreign workers who are vulnerable to friction with the existence of indigenous peoples.

Ternate City Regulation No. 13 of 2009 concerning the Protection of Indigenous and Cultural Rights of Indigenous Peoples, the Sultanate of Ternate is unable to accommodate new problems because the regional regulations only contain standard rules surrounding the sultanate including:

Customs are values/norms that apply from generation to generation, which regulate human relations with the Creator, the relationship between the community and the leader on the contrary also regulates the relationship between the leader and the community and the relationship between the community and the community consisting of a. Adat se Atorang are habits that apply from generation to generation that form the values implemented by the community;

b. Adat Kabasaran are the habits of the people who are respected and upheld by their greatness values;

c. Ghalib se Lukudi is an acknowledgment of human existence as a creature created by God Almighty and he cannot live alone but as social beings who are interconnected with each other; 
d. Cing se Cingari is an attitude and action that must be obeyed and maintained for the common good; Bobaso se Rasai is tolerance and respect for each other and is aware of being God's creatures

e. Ngale se Cara are attitudes and actions that provide benefits both to oneself and to fellow human beings;

f. Sere se Duniru are people's habits in the form of traditional arts that are preserved from generation to generation;

Meanwhile, in the field implementation, a new problem was found that the existence of customary lands is highly threatened by individual and company control.

Some traditional leaders informed that the potential potential in their territory is increasing day by day, in accordance with the government program that to boost State Foreign Exchange, the government really expects from the tourism sector because tourism is one of the leading sectors, tourism is targeted to earn foreign exchange up to 17.6 billion US dollars and attracting 20 million foreign tourists (tourists) by the end of 2019, the government has launched several programs including 1). Accelerating the completion of infrastructure projects, which will be carried out by the government is accelerating the completion of several infrastructure projects, it is aimed at increasing accessibility and supporting an increase in the number of foreign tourist visits, 2).Encouraging the development of tourist attractions in border areas or cross-border tourism by holding various cultural attractions. periodically. In addition, the development of tourist attractions for the quality tourist segment will also be carried out by determining the carrying capacity in tourist destination areas, 3). Improving the quality of amenities, this is done through efforts to accelerate land acquisition for the development of amenities in priority destinations, 4). To strengthen tourism promotion, these steps were taken, among others, through digital promotions (marketplaces), development of tour packages, expansion of tourism promo packages (hot deals) in a number of tourist destinations, as well as promotions in several locations that are regional tourism hubs. 5). Encouraging investment and selection in destination development, as well as increasing tourism human resources, improving data and information support, including publishing standardization publications and business activities for classifying tourist expenditures. This is done through coordination with the Indonesian Embassy in relation to tourism activities. 6). Issuance of technical guidelines for people's business credit (KUR) for tourism as well as increasing human resource capacity in a number of tourist destinations through vocational education and certification programs in the tourism sector.

With this government priority program, new problems will automatically arise among indigenous peoples who are actually the owners of areas that have been inhabited for generations, while indigenous peoples are vulnerable to understanding land rights and others in accordance with the Basic Agrarian Law, while in the event of a dispute or taking customary land for tourism development purposes, the recognized land regulations are based on the Basic Agrarian Law

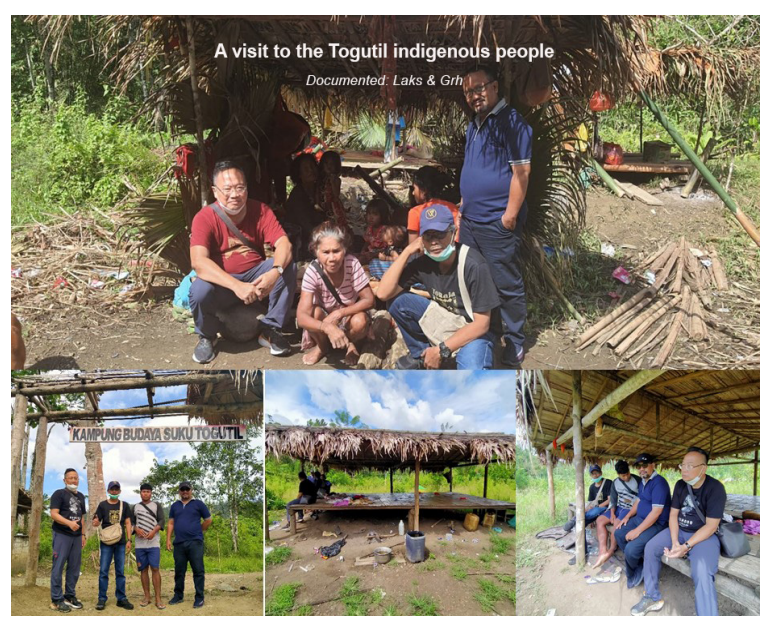

Figure 3. A visit to the toguttil indigenous people

The counseling was directed to accelerate the importance of hastening the PERDA of Indigenous Peoples in Maba (the capital of East Halmahera) which regulates ulayat lands for existing adat communities. The Regional Regulation on Indigenous Peoples is very important and urgent to prevent conflicts between indigenous peoples, including the Togutil tribe with the community and other related lands. From several other cases, it was found that the issue of customary territory can lead to inter-tribal conflicts because they feel disturbed by the entry of residents into their territory, there is a shift and the indigenous Togutil indigenous peoples feel threatened for their territory. The Togutil indigenous people feel threatened and disturbed by their territory due to the absence of regulation by indigenous peoples in Haltim Regency to protect the lands and territories of their indigenous peoples.

In the topic of the PERDA drafting plan, the participants who are traditional leaders and regional leaders are very much appreciated, it is planned that the PERDA draft will be drawn up involving the Regional Apparatus Work Units (SKPD) to the Regency level with the assistance of experts from the Faculty of Law, Sahid University and the Faculty of Economics and Business. Khairun University Ternate Law. The draft (draft) of the proposed Customary Regional Regulation in East Halmehera Maba Regency is essentially to regulate customary land for existing customary communities. The Regional Regulation on Indigenous Peoples is very important and urgent to prevent conflicts between indigenous peoples, such as Togutil with the community and others related to land, this is based on preventing acts of violence due to lack of understanding, one example in the mass media is that the attacks that had occurred were carried out by the Togutil tribe who killed 3 people in the Gowenly River in the forest in Masure Village, East Farmer, Central Halmahera, allegedly because they felt 
disturbed by the entry of residents into their territory which had been inhabited for generations. The continuation of the Togutil indigenous peoples over their territory due to the absence of customary community regulations in East Halmahera Regency to protect the lands and territories of their indigenous peoples, this is related to and the tourism potential that has not been explored, namely the beauty of Pasir Putih beach, East Maba which is suitable for diving and surfing in connection with with the local wisdom of indigenous peoples in Bicoli, Maba, East Halmahera. The East Halmahera Regional Government and the police, Polda Malut, must look carefully at the indigenous peoples (the Togutil tribe) who feel disturbed and threatened in their territory.

\section{CONCLUSION}

Recognition of indigenous peoples in the regulatory framework in the regions as a forum for carrying out social empowering or strengthening communities to manage and protect their customary territories, communities as subjects of development, especially indigenous peoples, must of course pay attention to their rights in every development process, considering their involvement and participation they are in development is very necessary.

Local governments must recognize, protect and empower traditional institutions that have existed for generations and/or form new customary institutions in customary law communities according to local customary law based on customary agreements and involve them in designing and making joint regulations.

The settlement area for the customary law community in the Maba district of East Halmahera can be designated as a traditional village in accordance with the provisions of the legislation and provide legal certainty regarding the existence, customary territory, customary forest and rights of indigenous peoples and strengthen access, participation and improve their welfare.

\section{ACKNOWLEDGEMENT}

We would like to thank all parties who have provided assistance for this activity, namely: 1). Dean of the Faculty of Law, Khairun University and his staff, 2). The Head of the Master of Law Study Program at Khairun University and his teaching staff, Mr. Camat Bicoli, Maba East Halmahera Regency, all of whom have provided assistance in the form of permits as well as assistance and accommodation in organizing activities, 3). The head of the Sahid University research and community service institution who has provided administrative facilities in the form of licensing activities for carrying out this activity

\section{BIBLIOGRAPHY}

Boedi Harsono, Hukum Agraria Indonesia, Sejarah Pembentukan Undang-Undang Pokok Agraria, Isi dan Pelaksanaannya, Jilid 1, Hukum Tanah Nasional, Djambatan, Cetakan Kelima, Jakarta, 1994

Peraturan Daerah Kota Ternate No. 13 Tahun 2009 Tentang Perlindungan Hak-Hak Adat Dan Budaya Masyarakat Adat Kesultanan Ternate

Stefanus Laksanto Utomo, 2011, Penguasaan Tanah Masyarakat Adat (Studi Budaya Hukum Masyarakat Samin Di Desa Baturejo, Kecamatan Sukolilo Kabupaten Pati Provinsi Jawa Tengah). Disertasi Program Doktor Ilmu Hukum Universitas Diponegoro

Book :

Undang-Undang Negara Republik Indonesia Tahun 1945

Undang-Undang Nomor 5 tahun 1960 tentang Pokokpokok Dasar Agraria

https://ravel.kompas.com/read/2019/03/19/110700827/6langkah-pemerintah-tingkatkan-devisa-pariwisataindonesia? 